\title{
Immunohistochemical detection of CD133 is associated with tumor regression grade after chemoradiotherapy in rectal cancer
}

\author{
Kumiko Hongo • Shinsuke Kazama • \\ Eiji Sunami · Nelson H. Tsuno • Koki Takahashi • \\ Hirokazu Nagawa $\cdot$ Joji Kitayama
}

Received: 20 December 2011/ Accepted: 5 January 2012/Published online: 14 January 2012

(C) The Author(s) 2012. This article is published with open access at Springerlink.com

\begin{abstract}
CD133 has been identified as a putative cancer stem cell (CSC) marker in various cancers including colorectal cancer. The relation between CD133 expression and biological characteristics of colorectal cancer remains to be clarified. Protein expression of CD133 was immunohistochemically evaluated in surgical specimens of 225 patients with colorectal cancer who were treated by surgery, as well as those of 78 patients with rectal cancer who received preoperative chemoradiotherapy (CRT) followed by curative resection. The correlation between CD133 expression and clinicopathological features, tumor recurrence and overall survival was analyzed in both populations. Among 225 colorectal cancers without CRT, 93 (41.3\%) were positive for CD133 expression, which was enhanced in cases with advanced $\mathrm{T}$ stage and venous invasion. Moreover, CD133 was positive in 47 (60.3\%) of 78 cases with CRT, which was significantly higher than the CD133-positive rate in non-CRT specimens $(P=0.05)$. Expression of CD133 was independently correlated with the histological tumor regression grade $(P<0.01)$. These results suggest that $\mathrm{CD} 133$ is not a distinctive colorectal CSC marker; expression of CD133 is suggested to be one
\end{abstract}

K. Hongo $(\bowtie) \cdot S$. Kazama · E. Sunami · J. Kitayama Department of Surgical Oncology, Faculty of Medicine, The University of Tokyo, 7-3-1 Hongo, Bunkyo-ku,

Tokyo 113-8655, Japan

e-mail:kimikh@attglobal.net

N. H. Tsuno $\cdot$ K. Takahashi

Department of Transfusion Medicine, Faculty of Medicine,

The University of Tokyo, 7-3-1 Hongo, Bunkyo-ku,

Tokyo 113-8655, Japan

H. Nagawa

Japan Labour, Health and Welfare Organization,

Kawasaki, Japan of the key factors associated with resistance to CRT in colorectal cancer.

Keywords CD133 - Colorectal cancer .

Chemoradiotherapy $\cdot$ Immunohistochemical detection

\section{Introduction}

The cancer stem cell (CSC) model suggests that cancer cells exhibit a hierarchy, as do normal cells and that a small fraction of cancer cells are maintained as "cancer stem cells" with self-renewal and differentiating abilities [1]. Recently, many reports suggest this stem cell theory not only in leukemia [2] but also in solid cancers [3-7].

CD133 is a cell surface transmembrane glycoprotein that exists in cholesterol-rich domain lipid rafts and is well known as an important marker for a number of different CSC lineages [8]. Although its cellular function is not clear, CD133 has been identified as a candidate marker for CSCs in various solid cancers including colorectal cancer, because CD133-positive cells in colorectal cancer have properties of self-renewal and high tumorigenic potential [9-11]. In fact, CD133 was recognized as a specific marker for the isolation of CSCs from brain tumors [6, 12], prostate carcinoma [13], and liver carcinoma [14]. On the other hand, some studies have not shown CD133 to be a specific marker for colorectal cancer CSCs [15-17]. It has been reported that $\mathrm{CD} 133$ expression is not restricted to stem cells, because both CD133+ and CD133- metastatic colon cancer cells initiate tumors [15].

Another important feature of CSCs is that they are resistant to toxic environmental agents such as radiotherapy and chemotherapy, due to high expression of ATPbinding cassette $(\mathrm{ABC})$ transporters, active DNA-repair 
capacity, and resistance to apoptosis [18]. Previous reports have suggested a relation between CD133 and resistance to anti-cancer treatment. CD133-positive glioma cells develop radioresistance through activation of the DNA damage response [19] or by induction of autophagy [20]. Moreover, Saigusa et al. reported that CD133 mRNA level in rectal cancer specimens was elevated by chemoradiotherapy (CRT), suggesting that CD133 might contribute to radioresistance $[21,22]$. On the other hand, CD133 expression has been reported not to be selective for the radioresistant colon cancer cell population in vitro [17]. In terms of chemoresistance, Tadaro et al. [23] reported that CD133-positive colon cancer cells had more resistance to anti-cancer drugs through production of interleukin-4. However, we have shown that CD133-negative colon cancers were more chemoresistant through enhanced integrin signals [24]. The relation between CD133 and resistance to anti-cancer treatment is under debate.

In this study, therefore, we performed immunohistochemical examination of CD133 expression in surgically removed specimens of colorectal cancer and rectal cancer after preoperative chemoradiotherapy (CRT) and investigated the possible association between CD133 expression and resistance to $\mathrm{CRT}$.

\section{Materials and methods}

\section{Patients and tissue specimens}

The expression of CD133 was immunohistochemically evaluated in surgical specimens of 225 patients with colorectal cancer who underwent curative resection at the University of Tokyo Hospital from January 1991 to October 1995. As well, 78 patients with rectal cancer who received preoperative chemoradiotherapy (CRT) and curative resection from May 2003 to June 2010 at the same hospital were enrolled in this study. The patients who received CRT had cancer of the middle or lower rectum, whose depth had been estimated to be deeper than the muscularis propria. The 78 patients received preoperative CRT, which consisted of preoperative radiotherapy $(1.8 \mathrm{~Gy} \times 25$ fractions $=50.4$ Gy irradiation) and chemotherapy, which consisted of oral administration of a prodrug of 5-FU (300 mg/day) and leucovorin ( $75 \mathrm{mg} /$ day) during the entire course of radiotherapy. Clinicopathological features were analyzed based on the TMN classification of malignant tumors, 7th edition according to the International Union Against Cancer (UICC) [25] and the World Health Organization (WHO) histological criteria [26]. Post-CRT histological tumor regression was graded according to the Japanese Guidelines for Clinical and Pathological Studies on Carcinoma of the Colorectum, 7th edition [27] (Table 1). It was classified into four categories:
Table 1 Grade of tumor regression after chemoradiotherapy for rectal carcinoma

\begin{tabular}{cl}
\hline Grade & Tumor regression \\
\hline Grade 0 & No necrosis or regressive change \\
Grade 1 & \\
a & $>66.6 \%$ vital residual tumor cells \\
b & Approximately 33.3-66.6\% vital residual tumor cells \\
Grade 2 & $<33.3 \%$ vital residual tumor cells \\
Grade 3 & No vital residual tumor cells \\
\hline
\end{tabular}

grade 0 , neither necrosis nor regressive changes; grade 1a, $>2 / 3$ vital residual tumor cells; grade $1 \mathrm{~b}$, approximately $1 / 3$ to $2 / 3$ vital residual tumor cells; grade $2,<1 / 3$ vital residual tumor cells; grade 3 , no vital residual tumor cells. Specimens with no remaining cancer cells and only a fibrotic mass were excluded, because our immunohistochemical staining targeted residual cancer tissue.

Immunohistochemistry staining and evaluation

Consecutive 4- $\mu \mathrm{m}$ sections fixed in formalin and embedded in paraffin were immunohistochemically stained using the technique described below. Tissues were treated with xylene and ethanol, then washed with phosphate-buffered saline (PBS). Endogenous peroxidase was blocked with $3 \%$ hydrogen peroxidase solution in methanol for $15 \mathrm{~min}$. After washing with PBS, heat-induced antigen retrieval was performed in ethylenediaminetetraacetic acid buffer at pH 8.0. Tissues were washed with PBS and incubated with $5 \%$ BSA for $30 \mathrm{~min}$ to block non-specific protein. Each slide was incubated overnight at $4^{\circ} \mathrm{C}$ with primary antiCD133 antibody (AC133; Miltenyi Biotec, Auburn, CA, USA) at a dilution of 1:100. After washing the slides three times with PBS, they were incubated with a Dako Envision Kit (Dako, Carpinteria, CA, USA) following the manufacturer's recommended protocol. After three washes with PBS, each slide was incubated for $3 \mathrm{~min}$ in $2 \% 3,3^{\prime}$-diaminobenzidine tetrahydrochloride and $50 \mathrm{mM}$ tris-buffer ( $\mathrm{pH}$ 7.6) containing $0.3 \%$ hydrogen peroxidase as a chromogen. Meyer's hematoxylin (Sigma Chemical Co., St. Louis, MO) was used for counterstaining. Renal tubules were used as positive control. For negative control, the antibody was replaced with PBS. Expression of CD133 was defined as positive when CD133 staining was found in more than $5 \%$ of the entire tumor according to Maeda's method as described previously [28-30]. Referring to Maeda's method, slides were examined under a microscope at low power (from $40 \times$ to $200 \times$ ) to identify the region containing the highest percentage of CD133-positive cells (hot spot) in the cancer nest. Ten fields of the hot spot inside the tumor tissue were selected, and expression of CD133 was evaluated in 1,000 tumor cells (100 cells per 
field) under high power $(400 \times)$. Specimens were defined as positive for CD133 expression, if there were tumor cells distinctly stained by anti-CD133 antibodies [28]. This was examined independently by two pathologists (K.H. and S.K.) who were unaware of the clinical findings. Discrepancies between their findings were resolved by discussion. Their inter-observer agreement was calculated using $\kappa$-statistics [31]. The correlation between CD133 expression and clinicopathological features, tumor recurrence and overall survival was analyzed.

\section{Statistical analysis}

The statistical significance of differences was evaluated by $\chi^{2}$ test, Fisher's exact test, or non-paired Student's $t$ test, as appropriate. An association was considered significant when $P<0.05$. Actuarial overall survival and recurrencefree rates were analyzed by Kaplan-Meier method. The significance of several variables in relation to tumor regression grade after CRT was analyzed by logistic regression analysis in multivariate analysis.
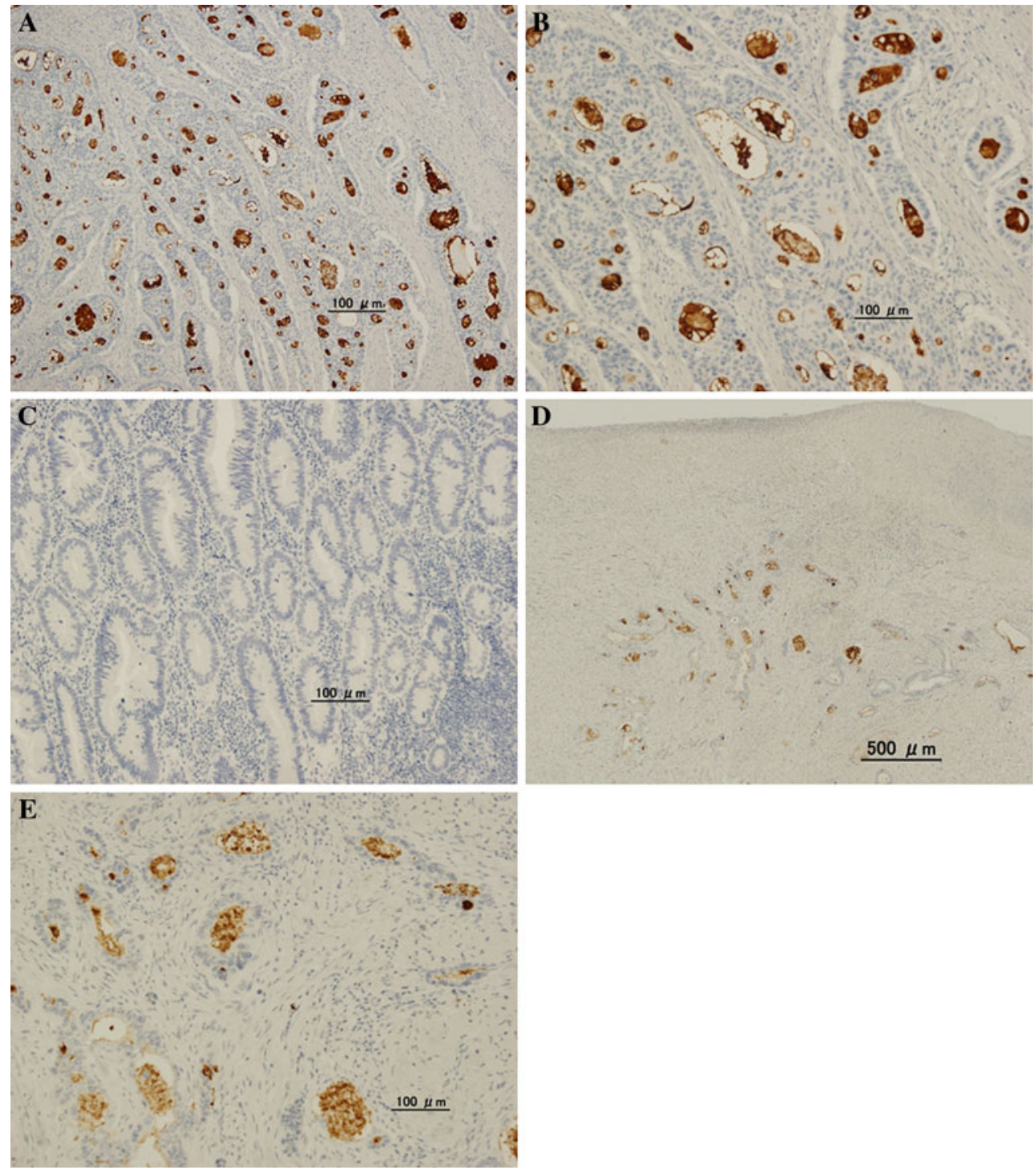

Fig. 1 Colorectal carcinoma without CRT (a-c) and with CRT (d, e) immunohistochemically stained using CD133 antibody. a Positive immunoreactivity for CD133 (original magnification, $\times 100$ ). b CD133 expression was seen on the luminal cell surface of colorectal cancer glands, and intraglandular cellular debris was seen in tumor glands with CD133-positive tumor cells (original magnification, $\times 400$ ). $\mathbf{c}$ Tumors showing no staining for CD133. d CD133 expression in residual cancer specimens with CRT (original magnification, $\times 40)$. e CD133 immunoreactivity was the same as that in those with surgery alone (original magnification, $\times 400$ ) 


\section{Results}

Expression of CD133 in colon cancer cells

CD133 expression was detected on the luminal cell surface of colorectal cancer glands and not in the cytoplasm in any case (Fig. 1). Additionally, intraglandular cellular debris was CD133 positive in some tumor glands. Such intraglandular staining was never detected where the glandular tumor cells were negative for CD133. This staining pattern was mostly similar to that previously reported [32, 33] and suggested that intraglandular cellular staining reflects shedding of surrounding CD133-positive tumor cells into the glandular lumina [32].

Relationship between clinicopathologic features and CD133 expression in colon cancer with surgery alone

The clinicopathological findings in the 225 patients with colorectal cancer who underwent surgery alone and the 78 patients with rectal cancer who underwent preoperative CRT and surgery are listed in Table 2. CD133 expression was detected in 93 of the 225 specimens with surgery alone (41.3\%). Each tumor was assessed as either positive or negative by two observers, giving an inter-observer agreement coefficient $\kappa$ of 0.79 . When comparing CD133 expression with clinicopathological variables, no correlation with age, sex, tumor size, lymph node metastasis, histologic appearance or lymphatic invasion was found (Table 3). CD133 expression was detected in 26 tumors of the right colon $(28.0 \%), 50(53.8 \%)$ of the left colon, and $17(18.2 \%)$ of the rectum, and CD133 expression was significantly lower in the rectum $(P=0.05)$. Additionally, there was significant correlation of CD133 expression with tumor depth $(P=0.05)$ and venous invasion $(P=0.03)$.

CD133 expression was detected in 47 of the 78 tumors with CRT $(60.3 \%)$. As in the group with surgery alone, no correlation with age, sex, tumor size, lymph node metastasis, histologic appearance or lymphatic invasion was found when comparing CD133 expression with clinicopathological variables (Table 3 ). In addition, tumor depth and venous invasion were not significantly different in the CRT group either.

CD133 expression in cancer of middle or low rectum

To investigate the possible effect of CRT on CD133 expression, we selected 26 cases of advanced rectal cancer with surgery alone located in the lower part of the rectum, which was the same population as the 78 cases in the CRT group, and compared their clinicopathological features (Table 4). Tumor size was significantly reduced in CRT
Table 2 Characteristics of colorectal cancer patients in this study

\begin{tabular}{|c|c|c|}
\hline & $\begin{array}{l}\text { Colorectal cancer } \\
\text { treated with } \\
\text { surgery alone }(n=225)\end{array}$ & $\begin{array}{l}\text { Rectal cancer treated with } \\
\text { chemoradiotherapy and } \\
\text { surgery }(n=78)\end{array}$ \\
\hline \multicolumn{3}{|l|}{ Gender } \\
\hline Male & $139(61.8 \%)$ & $47(60.3 \%)$ \\
\hline Female & $86(38.2 \%)$ & $31(39.7 \%)$ \\
\hline $\begin{array}{l}\text { Mean age } \\
\quad \text { (years) } \pm S D\end{array}$ & $63.4 \pm 10.9$ & $61.2 \pm 10.1$ \\
\hline $\begin{array}{l}\text { Tumor size } \\
\quad(\mathrm{mm}) \pm \mathrm{SD}\end{array}$ & $45.6 \pm 23.3$ & $44.9 \pm 8.4$ \\
\hline \multicolumn{3}{|l|}{ Location } \\
\hline Cecum (C) & $11(4.9 \%)$ & 0 \\
\hline $\begin{array}{l}\text { Ascending } \\
\text { colon }(\mathrm{A})\end{array}$ & $38(16.9 \%)$ & 0 \\
\hline $\begin{array}{l}\text { Transverse } \\
\text { colon }(\mathrm{T})\end{array}$ & $17(7.6 \%)$ & 0 \\
\hline $\begin{array}{c}\text { Descending } \\
\text { colon (D) }\end{array}$ & $4(1.8 \%)$ & 0 \\
\hline $\begin{array}{l}\text { Sigmoid } \\
\text { colon }(\mathrm{S})\end{array}$ & $97(43.1 \%)$ & 0 \\
\hline Rectum & $58(25.8 \%)$ & $78(100 \%)$ \\
\hline $\begin{array}{l}\text { Right-sided } \\
\text { colon }(\mathrm{C} / \mathrm{A})\end{array}$ & $50(22.2 \%)$ & \\
\hline $\begin{array}{l}\text { Left-sided } \\
\text { colon }(\mathrm{T} / \mathrm{D} / \mathrm{S})\end{array}$ & $117(52.0 \%)$ & \\
\hline Rectum & $58(25.8 \%)$ & \\
\hline \multicolumn{3}{|l|}{ Tumor depth } \\
\hline $\mathrm{T} 1$ & $18(8.0 \%)$ & $8(10.3 \%)$ \\
\hline $\mathrm{T} 2$ & $25(15.6 \%)$ & $22(28.2 \%)$ \\
\hline $\mathrm{T} 3$ & $165(73.3 \%)$ & $43(55.1 \%)$ \\
\hline $\mathrm{T} 4$ & $7(3.1 \%)$ & $5(6.4 \%)$ \\
\hline \multicolumn{3}{|l|}{ Histologic type } \\
\hline Well & $172(76.4 \%)$ & $52(66.7 \%)$ \\
\hline Moderately & $45(20.1 \%)$ & $24(30.8 \%)$ \\
\hline Mucinous & $3(1.3 \%)$ & $0(0.0 \%)$ \\
\hline Poorly & $5(2.2 \%)$ & $2(2.5 \%)$ \\
\hline \multicolumn{3}{|c|}{ Lymphatic invasion } \\
\hline Positive & $53(23.6 \%)$ & $7(9.0 \%)$ \\
\hline Negative & $172(76.4 \%)$ & $71(91.0 \%)$ \\
\hline \multicolumn{3}{|l|}{ Venous invasion } \\
\hline Positive & $136(60.4 \%)$ & $41(52.6 \%)$ \\
\hline Negative & $89(39.6 \%)$ & $37(47.4 \%)$ \\
\hline \multicolumn{3}{|c|}{ Lymph node metastasis } \\
\hline Positive & $88(39.1 \%)$ & $15(19.2 \%)$ \\
\hline Negative & $137(60.9 \%)$ & $63(80.8 \%)$ \\
\hline \multicolumn{3}{|l|}{ Stage } \\
\hline 1 & $43(19.1 \%)$ & $25(32.1 \%)$ \\
\hline 2 & $94(41.8 \%)$ & $33(42.3 \%)$ \\
\hline 3 & 87 (38.7\%) & $13(16.7 \%)$ \\
\hline 4 & $1(0.4 \%)$ & $7(9.0 \%)$ \\
\hline
\end{tabular}

C/A Cecum and ascending colon; $T / D / S$ transverse colon, descending colon and sigmoid colon 
Table 3 Correlation between clinicopathological features and CD133 expression

\begin{tabular}{|c|c|c|c|c|c|c|}
\hline & \multicolumn{3}{|c|}{$\begin{array}{l}\text { Colorectal cancer treated with surgery alone } \\
(n=225)\end{array}$} & \multicolumn{3}{|c|}{$\begin{array}{l}\text { Rectal cancer treated with chemoradiotherapy and surgery } \\
(n=78)\end{array}$} \\
\hline & CD133 positive & CD133 negative & $P$ value & CD133 positive & CD133 negative & $P$ value \\
\hline \multicolumn{7}{|l|}{ Gender } \\
\hline Male & $60(64.5 \%)$ & $79(59.8 \%)$ & 0.45 & $30(63.8 \%)$ & $17(54.8 \%)$ & 0.43 \\
\hline Female & $33(35.5 \%)$ & $53(40.2 \%)$ & & $17(36.2 \%)$ & $14(45.2 \%)$ & \\
\hline Mean age (years) $\pm S D$ & $64.6 \pm 9.5$ & $62.6 \pm 11.6$ & 0.92 & $60.2 \pm 10.7$ & $62.8 \pm 9.1$ & 0.36 \\
\hline Tumor size $(\mathrm{mm}) \pm \mathrm{SD}$ & $45.6 \pm 21.1$ & $45.5 \pm 24.9$ & 0.5 & $46.6 \pm 1.1$ & $42.5 \pm 1.2$ & 0.72 \\
\hline \multicolumn{7}{|l|}{ Location } \\
\hline Right-sided colon (C/A) & $26(28.0 \%)$ & $24(18.2 \%)$ & 0.05 & $0(0.0 \%)$ & $0(0.0 \%)$ & ND \\
\hline Left-sided colon (T/D/S) & $50(53.8 \%)$ & $67(50.8 \%)$ & & $0(0.0 \%)$ & $0(0.0 \%)$ & \\
\hline Rectum & $17(18.3 \%)$ & $41(31.0 \%)$ & & $47(60.3 \%)$ & $31(39.7 \%)$ & \\
\hline \multicolumn{7}{|l|}{ Tumor depth } \\
\hline $\mathrm{T} 1$ & $6(6.5 \%)$ & $12(9.1 \%)$ & 0.05 & $5(10.3 \%)$ & $3(9.7 \%)$ & 0.35 \\
\hline $\mathrm{T} 2$ & $17(18.2 \%)$ & $18(13.6 \%)$ & & $10(21.3 \%)$ & $12(38.7 \%)$ & \\
\hline $\mathrm{T} 3$ & $64(68.8 \%)$ & $101(76.5 \%)$ & & $28(59.6 \%)$ & $15(48.4 \%)$ & \\
\hline $\mathrm{T} 4$ & $6(6.5 \%)$ & $1(0.8 \%)$ & & $4(8.5 \%)$ & $1(3.2 \%)$ & \\
\hline \multicolumn{7}{|l|}{ Histologic type } \\
\hline Well & $76(81.7 \%)$ & $96(72.7 \%)$ & 0.18 & $31(66.0 \%)$ & $21(67.7 \%)$ & 0.35 \\
\hline Moderately & $16(17.2 \%)$ & $29(22.0 \%)$ & & $14(29.8 \%)$ & $10(32.3 \%)$ & \\
\hline Mucinous & $0(0.0 \%)$ & $3(2.3 \%)$ & & $2(4.3 \%)$ & $0(0.0 \%)$ & \\
\hline Poorly & $1(1.1 \%)$ & $4(3.0 \%)$ & & $0(0.0 \%)$ & $0(0.0 \%)$ & \\
\hline \multicolumn{7}{|l|}{ Lymphatic invasion } \\
\hline Positive & $23(24.7 \%)$ & $30(22.7 \%)$ & 0.73 & $5(10.6 \%)$ & $2(6.5 \%)$ & 0.52 \\
\hline Negative & $70(75.3 \%)$ & $102(77.3 \%)$ & & $42(89.4 \%)$ & $29(93.5 \%)$ & \\
\hline \multicolumn{7}{|l|}{ Venous invasion } \\
\hline Positive & $64(68.8 \%)$ & $72(54.6 \%)$ & 0.03 & $27(57.5 \%)$ & $14(45.2 \%)$ & 0.29 \\
\hline Negative & $29(31.2 \%)$ & $60(45.4 \%)$ & & $20(42.5 \%)$ & $17(54.8 \%)$ & \\
\hline \multicolumn{7}{|l|}{ Lymph node metastasis } \\
\hline Positive & $36(38.7 \%)$ & $52(39.4 \%)$ & 0.91 & $10(21.7 \%)$ & $5(16.1 \%)$ & 0.54 \\
\hline Negative & $57(61.3 \%)$ & $80(60.6 \%)$ & & $37(78.3 \%)$ & $26(83.9 \%)$ & \\
\hline \multicolumn{7}{|l|}{ Stage } \\
\hline 1 & $19(20.4 \%)$ & $24(18.2 \%)$ & 0.74 & $13(27.7 \%)$ & $12(38.7 \%)$ & 0.72 \\
\hline 2 & $38(40.9 \%)$ & $56(42.4 \%)$ & & $21(44.7 \%)$ & $12(38.7 \%)$ & \\
\hline 3 & $36(38.7 \%)$ & $51(38.6 \%)$ & & $9(19.1 \%)$ & $4(12.9 \%)$ & \\
\hline 4 & $0(0.0 \%)$ & $1(0.8 \%)$ & & $4(8.5 \%)$ & $3(9.7 \%)$ & \\
\hline
\end{tabular}

$N D$ Not detected

cases $(P<0.0001)$, and lymph node metastasis $(P=$ $0.02)$, lymphatic invasion $(P=0.03)$, and clinical stage $(P=0.01)$ were significantly reduced after CRT. On the other hand, $47(60.3 \%)$ of 78 tumors with preoperative CRT were CD133 positive, which was significantly higher than $10(38.5 \%)$ of 26 cases without CRT $(P=0.05)$.

Correlation between CD133 expression and histological tumor regression grade with CRT

CD133 expression showed a significant association with the tumor regression grade after CRT graded according to the Japanese Guidelines for Clinical and Pathological Studies on Carcinoma of the Colorectum, 7th edition [27] (Table 1). As shown in Table 5, 20 (64.5\%) of 31 tumors without CD133 expression showed a good histopathological response (grade 2), whereas only 10 (22.2\%) of 45 CD133-positive tumors were classified as responders (grade 2) $(P=0.0002)$. When we examined the correlation of CRT tumor regression grade with clinicopathological variables and the expression of CD133 by univariate and multivariate analysis, CD133 expression was recognized as an independent association factor affecting resistance to CRT $(P<0.01)$ (Table 6). 
Table 4 Clinicopathological features of patients treated with and without chemoradiotherapy for middle/lower rectal cancer

\begin{tabular}{|c|c|c|c|}
\hline & Without CRT & With CRT & $P$ value \\
\hline \multicolumn{4}{|l|}{ Gender } \\
\hline Male & $16(61.5 \%)$ & $47(60.3 \%)$ & \multirow[t]{2}{*}{0.8} \\
\hline Female & $10(38.5 \%)$ & $31(39.7 \%)$ & \\
\hline Mean age (years) $\pm \mathrm{SD}$ & $60.8 \pm 10.2$ & $61.2 \pm 10.1$ & 0.83 \\
\hline Tumor size $(\mathrm{mm}) \pm \mathrm{SD}$ & $36.9 \pm 17.0$ & $4.5 \pm 7.3$ & $<0.0001$ \\
\hline \multicolumn{4}{|l|}{ Tumor depth } \\
\hline $\mathrm{T} 1$ & $2(7.7 \%)$ & $8(10.3 \%)$ & \multirow[t]{4}{*}{0.3} \\
\hline $\mathrm{T} 2$ & $10(38.5 \%)$ & $22(28.2 \%)$ & \\
\hline $\mathrm{T} 3$ & $14(53.8 \%)$ & $43(55.1 \%)$ & \\
\hline $\mathrm{T} 4$ & $0(0.0 \%)$ & $5(6.4 \%)$ & \\
\hline \multicolumn{4}{|l|}{ Histologic type } \\
\hline Well & $20(76.9 \%)$ & $52(67.5 \%)$ & \multirow[t]{3}{*}{0.4} \\
\hline Moderately & $6(23.1 \%)$ & $24(30.0 \%)$ & \\
\hline Mucinous & $0(0.0 \%)$ & $2(2.5 \%)$ & \\
\hline \multicolumn{4}{|l|}{ Lymphatic invasion } \\
\hline Positive & $7(26.9 \%)$ & $7(9.0 \%)$ & \multirow[t]{2}{*}{0.03} \\
\hline Negative & $19(73.1 \%)$ & $71(91.0 \%)$ & \\
\hline \multicolumn{4}{|l|}{ Venous invasion } \\
\hline Positive & $17(65.4 \%)$ & $41(52.6 \%)$ & \multirow[t]{2}{*}{0.25} \\
\hline Negative & $9(34.6 \%)$ & $37(47.4 \%)$ & \\
\hline \multicolumn{4}{|l|}{ Lymph node metastasis } \\
\hline Positive & $11(42.3 \%)$ & $15(19.0 \%)$ & \multirow[t]{2}{*}{0.02} \\
\hline Negative & $15(57.7 \%)$ & $63(81.0 \%)$ & \\
\hline \multicolumn{4}{|l|}{ Stage } \\
\hline 1 & $10(38.5 \%)$ & $25(32.1 \%)$ & \multirow[t]{4}{*}{0.01} \\
\hline 2 & $5(19.2 \%)$ & $33(42.3 \%)$ & \\
\hline 3 & $11(42.3 \%)$ & $13(16.7 \%)$ & \\
\hline 4 & $0(0.0 \%)$ & $7(9.0 \%)$ & \\
\hline \multicolumn{4}{|l|}{ CD133 expression } \\
\hline Positive & $10(38.5 \%)$ & $47(60.3 \%)$ & \multirow[t]{2}{*}{0.05} \\
\hline Negative & $16(61.5 \%)$ & $31(39.7 \%)$ & \\
\hline
\end{tabular}

CRT Chemoradiotherapy

Table 5 Correlation between tumor regression grade and CD133 expression

\begin{tabular}{clcc}
\hline & \multicolumn{3}{l}{ Rectal cancer treated with chemoradiotherapy $(n=78)$} \\
\cline { 2 - 4 } & CD133 positive & CD133 negative & $P$ value \\
\hline \multicolumn{2}{c}{ Tumor regression grade } & & \\
$1 \mathrm{a}$ & $20(44.4 \%)$ & $3(9.7 \%)$ & 0.0002 \\
$1 \mathrm{~b}$ & $15(33.3 \%)$ & $8(25.8 \%)$ & \\
2 & $10(22.2 \%)$ & $20(64.5 \%)$ & \\
\hline
\end{tabular}

Recurrence-free survival and overall survival analysis of colon cancer in relation to CD133 expression

Finally, we examined the relation between CD133 expression and the outcome of patients using Kaplan-
Table 6 Univariate and multivariate analysis of factors related to tumor regression grade

\begin{tabular}{lllc}
\hline Factors & $\begin{array}{l}\text { Univariate } \\
\text { analysis }\end{array}$ & $\begin{array}{l}\text { Multivariate } \\
\text { analysis }\end{array}$ & $\begin{array}{l}\text { Odds ratio } \\
(95 \% \mathrm{CI})\end{array}$ \\
\hline $\begin{array}{l}\text { Tumor size } \\
\text { Tumor depth }\end{array}$ & 0.93 & $P$ value & \\
$\begin{array}{l}\text { Histology } \\
\text { Lymphatic invasion }\end{array}$ & 0.11 & & \\
$\begin{array}{l}\text { Venous invasion } \\
\text { Lymph node }\end{array}$ & 0.28 & & \\
$\quad 0.0024$ & 0.0033 & $4.9(-1.56$ \\
metastasis & 0.55 & & \\
CD133 expression & 0.0002 & $0.44)$ & \\
& & & 0.0003 \\
\hline
\end{tabular}

CI Confidence interval

Meier analysis and log-rank test. As shown in Fig. 2a, there was no significant correlation between CD133 expression and overall survival (OS) rate in colorectal cancer patients without CRT. In patients with CRT, however, CD133positive cases tended to have shorter OS, although the difference did not reach statistical significance (Fig. 2b).

\section{Discussion}

Recent studies on the biological importance of CSCs have suggested many putative molecular markers for CSCs in solid tumors. In particular, CD133 is considered to be a representative marker for CSCs in various malignancies, which led to extensive immunohistochemical studies to characterize the expression and distribution of this molecule in human samples. In colorectal cancer, Horst et al. reported that patients with high CD133-expressing tumors had significantly worse overall survival $[32,34]$ and disease-free survival [34] than those with low CD133expressing tumors. More recently, Ong et al. [35] also demonstrated the same results in more than 500 patients. Kojima et al. [36] also reported that CD133 is highly expressed in well/moderately differentiated, but not in poorly differentiated tumors. On the other hand, Choi et al. [37] reported that there was a relation between CD133 expression and invasiveness and differentiation, but no relation with survival, and Lugli et al. [30] showed no correlation between CD133 and any clinicopathological feature or survival time. Therefore, the clinical relevance of CD133 expression in colorectal cancer is still controversial.

In this study, we further investigated the expression of CD133 using the same approach in colorectal cancer including tumors subjected to preoperative CRT. Our 
Fig. 2 Kaplan-Meier plot showing survival time of colorectal cancer patients with surgery alone (a) and of rectal cancer patients with preoperative CRT (b)
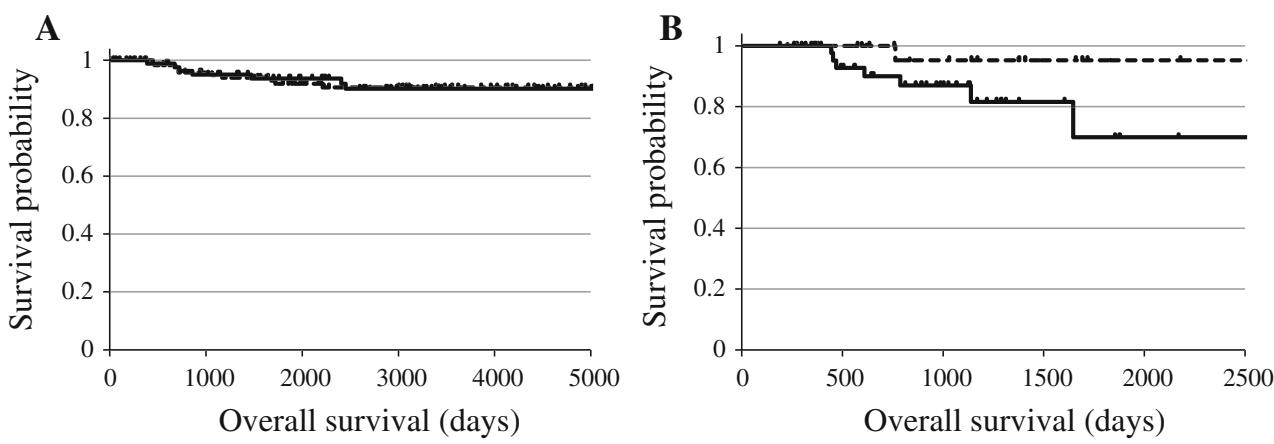

$\mathrm{P}=0.98$ results in the surgery alone group showed a significant association between expression of CD133 and tumor depth and venous invasion, which was mostly consistent with other studies [37, 38]. This finding appears to be reasonable, since CD133-positive colon cancer cells have been reported to exhibit more invasive ability than negative ones, both in vitro [11] and in vivo [39].

In our series, rectal cancer showed lower expression of CD133 than that in colonic cancer, which was not described in previous studies. Also, expression of CD133 was revealed to be more common after CRT. More importantly, CD133-positive cases tended to have shorter overall survival, although CD133 expression showed no correlation with recurrence-free survival (data not shown). This trend was not observed in the 225 cases of colorectal cancer without CRT that underwent surgery in 1991-1995. Since all of the recurrent CRT cases, but none of the non-CRT cases, were treated with recent chemotherapeutic regimens including oxaliplatin or irinotecan, this might suggest that CD133 expression in irradiated tumor cells may be associated with the potential for resistance to these chemotherapeutic agents, as Ong et al. [35] reported previously.

Another important finding in this study is that CD133 expression was detected more frequently in rectal cancers with CRT than in the surgery alone group. The same finding has been reported in other studies [38, 40, 41]. Moreover, CD133 mRNA level in rectal cancer specimens was elevated by CRT [21, 22]. Our results additionally showed that CD133 expression was significantly correlated with histological tumor regression grade. Specimens with expression of CD133 showed less response to CRT, and thus, CD133-positive cells may have reduced sensitivity to chemoradiation. In glioblastoma cells, CD133-positive cells were shown to have reduced sensitivity to radiation and survived radiation damage through activation of DNA damage repair [19, 42]. Additionally, CD133 expression in colon cancer cells, HT29, was reported to be increased in a radiation-dependent manner. They had reduced sensitivity to radiation and survived radiation damage through induction of cell cycle arrest or cell dormancy, based on the finding that some CD133-positive cells lacked Ki-67 expression [41]. These in vitro results suggest that both mechanisms may contribute to the enrichment of CD133positive cells in rectal cancer tissue after CRT.

Furthermore, extrinsic cues, the so-called niche, provided by cells and extracellular matrix components of the stem cell microenvironment have been recognized to be critical in stem cell regulation [43]. This means that CD133 needs a specific microenvironment to demonstrate these mechanisms of resistance to CRT. Hypoxia has been recognized to be a specific microenvironment, or "niche," regulating stem cell abilities including self-renewal, differentiation, maturation, and homing [44]. In fact, it is also reported that hypoxia was an essential "niche" for CD133 to maintain CSC ability in glioblastoma [45]. On the other hand, hypoxia is known to be significantly correlated with resistance to preoperative CRT in rectal cancer [46, 47]. Considering these facts, it is suggested that a hypoxic niche may contribute to enhanced CD133 expression after CRT in rectal cancer tissue and may also affect the prognosis of patients.

In summary, CD133 expression may be related to sensitivity to radiotherapy or chemotherapy in colorectal cancer. However, the immunohistochemical results of previous studies including ours are only partly consistent with each other, which suggest the presence of functional subtypes of CD133-positive cancer cells and support the concept that CSCs in colorectal cancer cannot be identified by CD133 expression alone. In fact, many other molecules such as CD44 [9, 11, 16, 48, 49] and CD24 [4] have been proposed as additional putative markers for CSCs in colorectal cancer. Accurate detection of "real" CSCs in human samples would be required to develop a novel treatment strategy targeting CSCs in colorectal cancer.

Conflict of interest None. 
Open Access This article is distributed under the terms of the Creative Commons Attribution Noncommercial License which permits any noncommercial use, distribution, and reproduction in any medium, provided the original author(s) and source are credited.

\section{References}

1. Reya T, Morrison SJ, Clarke MF, Weissman IL. Stem cells, cancer, and cancer stem cells. Nature. 2001;414(6859):105-11. doi: $10.1038 / 35102167$.

2. Lapidot T, Sirard C, Vormoor J, Murdoch B, Hoang T, CaceresCortes $\mathrm{J}$, et al. A cell initiating human acute myeloid leukaemia after transplantation into SCID mice. Nature. 1994;367(6464): 645-8. doi:10.1038/367645a0.

3. Kim CF, Jackson EL, Woolfenden AE, Lawrence S, Babar I, Vogel S, et al. Identification of bronchioalveolar stem cells in normal lung and lung cancer. Cell. 2005;121(6):823-35. doi: 10.1016/j.cell.2005.03.032.

4. Al-Hajj M, Wicha MS, Benito-Hernandez A, Morrison SJ, Clarke MF. Prospective identification of tumorigenic breast cancer cells. Proc Natl Acad Sci USA. 2003;100(7):3983-8. doi:10.1073/pnas. 0530291100.

5. Kondo T, Setoguchi T, Taga T. Persistence of a small subpopulation of cancer stem-like cells in the C6 glioma cell line. Proc Natl Acad Sci USA. 2004;101(3):781-6. doi:10.1073/pnas. 0307618100.

6. Singh SK, Hawkins C, Clarke ID, Squire JA, Bayani J, Hide T, et al. Identification of human brain tumour initiating cells. Nature. 2004;432(7015):396-401. doi:10.1038/nature03128.

7. Wang S, Garcia AJ, Wu M, Lawson DA, Witte ON, Wu H. Pten deletion leads to the expansion of a prostatic stem/progenitor cell subpopulation and tumor initiation. Proc Natl Acad Sci USA. 2006;103(5):1480-5. doi:10.1073/pnas.0510652103.

8. Shmelkov SV, St Clair R, Lyden D, Rafii S. AC133/CD133/ Prominin-1. Int J Biochem Cell Biol. 2005;37(4):715-9. doi: 10.1016/j.biocel.2004.08.010.

9. O'Brien CA, Pollett A, Gallinger S, Dick JE. A human colon cancer cell capable of initiating tumour growth in immunodeficient mice. Nature. 2007;445(7123):106-10. doi:10.1038/nature 05372 .

10. Ricci-Vitiani L, Lombardi DG, Pilozzi E, Biffoni M, Todaro M, Peschle $\mathrm{C}$, et al. Identification and expansion of human coloncancer-initiating cells. Nature. 2007;445(7123):111-5. doi: 10.1038/nature05384.

11. Ieta K, Tanaka F, Haraguchi N, Kita Y, Sakashita H, Mimori K, et al. Biological and genetic characteristics of tumor-initiating cells in colon cancer. Ann Surg Oncol. 2008;15(2):638-48. doi: 10.1245/s10434-007-9605-3.

12. Singh SK, Clarke ID, Terasaki M, Bonn VE, Hawkins C, Squire $\mathrm{J}$, et al. Identification of a cancer stem cell in human brain tumors. Cancer Res. 2003;63(18):5821-8.

13. Collins AT, Berry PA, Hyde C, Stower MJ, Maitland NJ. Prospective identification of tumorigenic prostate cancer stem cells. Cancer Res. 2005;65(23):10946-51. doi:10.1158/0008-5472. CAN-05-2018.

14. Ma S, Chan KW, Hu L, Lee TK, Wo JY, Ng IO, et al. Identification and characterization of tumorigenic liver cancer stem/ progenitor cells. Gastroenterology. 2007;132(7):2542-56. doi: 10.1053/j.gastro.2007.04.025.

15. Shmelkov SV, Butler JM, Hooper AT, Hormigo A, Kushner J, Milde T, et al. CD133 expression is not restricted to stem cells, and both CD133+ and CD133 - metastatic colon cancer cells initiate tumors. J Clin Invest. 2008;118(6):2111-20. doi:10.1172/ JCI34401.
16. Du L, Wang H, He L, Zhang J, Ni B, Wang X, et al. CD44 is of functional importance for colorectal cancer stem cells. Clin Cancer Res. 2008;14(21):6751-60. doi:10.1158/1078-0432. CCR-08-1034.

17. Dittfeld C, Dietrich A, Peickert S, Hering S, Baumann M, Grade $\mathrm{M}$, et al. CD133 expression is not selective for tumor-initiating or radioresistant cell populations in the CRC cell lines HCT-116. Radiother Oncol. 2009;92(3):353-61. doi:10.1016/j.radonc.2009. 06.034 .

18. Dean M, Fojo T, Bates S. Tumour stem cells and drug resistance. Nature Rev Cancer. 2005;5(4):275-84. doi:10.1038/nrc1590.

19. Bao S, Wu Q, McLendon RE, Hao Y, Shi Q, Hjelmeland AB, et al. Glioma stem cells promote radioresistance by preferential activation of the DNA damage response. Nature. 2006;444 (7120):756-60. doi:10.1038/nature05236.

20. Lomonaco SL, Finniss S, Xiang C, Decarvalho A, Umansky F, Kalkanis SN, et al. The induction of autophagy by gamma-radiation contributes to the radioresistance of glioma stem cells. Int $\mathrm{J}$ Cancer. 2009;125(3):717-22. doi:10.1002/ijc.24402.

21. Saigusa S, Tanaka K, Toiyama Y, Yokoe T, Okugawa Y, Ioue Y, et al. Correlation of CD133, OCT4, and SOX2 in rectal cancer and their association with distant recurrence after chemoradiotherapy. Ann Surg Oncol. 2009;16(12):3488-98. doi:10.1245/s 10434-009-0617-z.

22. Yasuda H, Tanaka K, Saigusa S, Toiyama Y, Koike Y, Okugawa $\mathrm{Y}$, et al. Elevated CD133, but not VEGF or EGFR, as a predictive marker of distant recurrence after preoperative chemoradiotherapy in rectal cancer. Oncol Rep. 2009;22(4):709-17.

23. Todaro M, Alea MP, Di Stefano AB, Cammareri P, Vermeulen L, Iovino $\mathrm{F}$, et al. Colon cancer stem cells dictate tumor growth and resist cell death by production of interleukin-4. Cell Stem Cell. 2007;1(4):389-402. doi:10.1016/j.stem.2007.08.001.

24. Hongo K, Tanaka J, Tsuno NH, Kawai K, Nishikawa T, Shuno Y, et al. CD133(-) cells, derived from a single human colon cancer cell line, are more resistant to 5-fluorouracil (FU) than CD133(+) cells, dependent on the beta1-integrin signaling. J Surg Res. 2011. doi: $10.1016 /$ j.jss.2011.03.076.

25. TNM Classification of Malignant Tumours, 7th ed (2009).

26. International Classification of Diseases for Oncology (2000).

27. General Rules for Clinical and Pathological Studies on Cancer of the Colon, Rectum, and Anus (2006).

28. Maeda S, Shinchi H, Kurahara H, Mataki Y, Maemura K, Sato M, et al. CD133 expression is correlated with lymph node metastasis and vascular endothelial growth factor-C expression in pancreatic cancer. Br J Cancer. 2008;98(8):1389-97. doi:10.1038/sj.bjc. 6604307.

29. Li CY, Li BX, Liang Y, Peng RQ, Ding Y, Xu DZ, et al. Higher percentage of CD133+ cells is associated with poor prognosis in colon carcinoma patients with stage IIIB. J Transl Med. 2009;7:56. doi:10.1186/1479-5876-7-56.

30. Lugli A, Iezzi G, Hostettler I, Muraro MG, Mele V, Tornillo L, et al. Prognostic impact of the expression of putative cancer stem cell markers CD133, CD166, CD44s, EpCAM, and ALDH1 in colorectal cancer. Br J Cancer. 2010;103(3):382-90. doi:10.1038/ sj.bjc.6605762.

31. Viera AJ, Garrett JM. Understanding interobserver agreement: the kappa statistic. Fam Med. 2005;37(5):360-3.

32. Horst D, Kriegl L, Engel J, Kirchner T, Jung A. CD133 expression is an independent prognostic marker for low survival in colorectal cancer. Br J Cancer. 2008;99(8):1285-9. doi:10.1038/ sj.bjc. 6604664 .

33. Kojima M, Ishii G, Atsumi N, Fujii S, Saito N, Ochiai A. Immunohistochemical detection of CD133 expression in colorectal cancer: a clinicopathological study. Cancer Sci. 2008;99 (8):1578-83. doi:10.1111/j.1349-7006.2008.00849.x. 
34. Horst D, Kriegl L, Engel J, Jung A, Kirchner T. CD133 and nuclear beta-catenin: the marker combination to detect high risk cases of low stage colorectal cancer. Eur $\mathrm{J}$ Cancer. 2009;45(11):2034-40. doi:10.1016/j.ejca.2009.04.004.

35. Ong CW, Kim LG, Kong HH, Low LY, Iacopetta B, Soong R, et al. CD133 expression predicts for non-response to chemotherapy in colorectal cancer. Mod Pathol. 2010;23(3):450-7. doi: 10.1038/modpathol.2009.181.

36. Kojima M, Ishii G, Atsumi N, Fujii S, Saito N, Ochiai A. Immunohistochemical detection of CD133 expression in colorectal cancer: a clinicopathological study. Cancer Sci. 2008;99 (8):1578-83. doi:10.1111/j.1349-7006.2008.00849.x.

37. Choi D, Lee HW, Hur KY, Kim JJ, Park GS, Jang SH, et al. Cancer stem cell markers CD133 and CD24 correlate with invasiveness and differentiation in colorectal adenocarcinoma. World J Gastroenterol. 2009;15(18):2258-64.

38. Wang Q, Chen ZG, Du CZ, Wang HW, Yan L, Gu J. Cancer stem cell marker CD133+ tumour cells and clinical outcome in rectal cancer. Histopathology. 2009;55(3):284-93. doi:10.1111/j. 1365-2559.2009.03378.x.

39. Li G, Liu C, Yuan J, Xiao X, Tang N, Hao J, et al. CD133(+) single cell-derived progenies of colorectal cancer cell line SW480 with different invasive and metastatic potential. Clin Exp Metastasis. 2010;27(7):517-27. doi:10.1007/s10585-010-9341-0.

40. Kojima M, Ishii G, Atsumi N, Nishizawa Y, Saito N, Ochiai A. CD133 expression in rectal cancer after preoperative chemoradiotherapy. Cancer Sci. 2010;101(4):906-12. doi:10.1111/j.13497006.2009.01478.x.
41. Saigusa S, Tanaka K, Toiyama Y, Yokoe T, Okugawa Y, Kawamoto A, et al. Immunohistochemical features of CD133 expression: association with resistance to chemoradiotherapy in rectal cancer. Oncol Rep. 2010;24(2):345-50.

42. Lomonaco SL, Finniss S, Xiang C, Decarvalho A, Umansky F, Kalkanis SN, et al. The induction of autophagy by gamma-radiation contributes to the radioresistance of glioma stem cells. Int J Cancer. 2009;125(3):717-22. doi:10.1002/ijc.24402.

43. Haylock DN, Nilsson SK. Stem cell regulation by the hematopoietic stem cell niche. Cell Cycle. 2005;4(10):1353-5.

44. De Filippis L, Delia D. Hypoxia in the regulation of neural stem cells. Cell Mol Life Sci. 2011. doi:10.1007/s00018-011-0723-5.

45. Bar EE, Lin A, Mahairaki V, Matsui W, Eberhart CG. Hypoxia increases the expression of stem-cell markers and promotes clonogenicity in glioblastoma neurospheres. Am J Pathol. 2010;177(3):1491-502. doi:10.2353/ajpath.2010.091021.

46. Guedj N, Bretagnol F, Rautou PE, Deschamps L, Cazals-Hatem $\mathrm{D}$, Bedossa $\mathrm{P}$, et al. Predictors of tumor response after preoperative chemoradiotherapy for rectal adenocarcinomas. Hum Pathol. 2011. doi:10.1016/j.humpath.2011.01.015.

47. Wilson WR, Hay MP. Targeting hypoxia in cancer therapy. Nat Rev Cancer. 2011;11(6):393-410. doi:10.1038/nrc3064.

48. Jemal A, Siegel R, Ward E, Murray T, Xu J, Smigal C, et al. Cancer statistics, 2006. CA Cancer J Clin. 2006;56(2):106-30. doi:56/2/106

49. Fidler IJ. The pathogenesis of cancer metastasis: the 'seed and soil' hypothesis revisited. Nat Rev Cancer. 2003;3(6):453-8. doi: 10.1038/nrc1098. 